\title{
Screening of Elite Genotypes of Tomato against Major TOSPO Vector- Thrips Complex
}

\author{
Pritha Ghosh $^{1}$, K. S. Jagadish ${ }^{1}$, M. G. Puroshottama ${ }^{2}$, V. Sridhar ${ }^{3}$ and Keshava Reddy ${ }^{1}$ \\ ${ }^{1}$ Department of Entomology, GKVK, UAS, Banglore 560065, Karnataka, India \\ ${ }^{2}$ M/s.I\&B Seeds Pvt. Ltd., Kengeri-Uttarahalli Main Road, Bengaluru-560060, India \\ ${ }^{3}$ Division of Entomology, IIHR, Bengaluru-560089, India \\ *Corresponding author
}

\section{A B S T R A C T}

\section{Keywords}

Wild accession,

Thrips resistance,

Trichome density

\section{Article Info}

Accepted:

15 November 2019

Available Online:

10 December 2019
Tomato is the second most important vegetable grown in India. It faces heavy attack by pest and diseases in tropical countries. Biotic and abiotic stress is major challenge for higher production of tomatoes. Thrips complex are important sucking pests which also cause more damage as vector species for virus diseases. So controlling the vector by screening against thrips damage/preference is the major concern for screening and developing lines resistant to thrips. Five elite lines were procured from World Vegetable Centre, AVRDC, Taiwan. Field screening and lab screening was carried out for evaluating thrips resistance. Four different thrip species viz., Thrips palmi, Scirtothrips dorsalis, Gynaikothrips uzeli and Thrips hawaiiensis were recorded in two dry seasons from collected thrips complex. Thrips count/tap was significantly less or almost nill in two wild accessions Solanum galapagense (VI037241) and S.cheesmaniae (VI037240) than susceptible genotype Solanum lycopersicum (CL5915)/(CH45). Although total thrips count was more in Solanum habrochaites and Solanum habrochaites var glabratum but in lab assay it showed less preference for egg laying and also in terms of feeding. In vitro leaf disc assay has shown high mortality of larva and entrapped larvae died because of sticky exudates from high glandular trichomes. Field screening has shown high resistance to two of the wild accessions in terms of thrips catch/tap. Lab assay has shown less preference to all the four wild accessions for egg laying and feeding except S.lycopersicum(CL5915). These assays can help to get an insight about high glandular trichome density and thrips resistance which can help in developing TOSPO virus resistant lines for future.

\section{Introduction}

Tomato is the second most important vegetable crop in India just after potato. India is a great contributor for vegetable industries in terms of its production. Though a range of factors contribute to the low yields, insect pests and diseases have been found to be the most damaging (Kagezi et al., 2001; Karungi et al., 2009). The most important insect pests afflicting the crops are aphids, whiteflies, thrips, African bollworm, and mites (Defrancq, 1989; Mwaule, 1995; Kagezi et al., 2001; Ssekyewa, 2006). Besides being important sucking pests, thrips also transmit the deadly tospo viruses in tomato in a persistent and propagative manner. The successful transmission of tospo virus by 
thrips involves the acquisition of the virus followed by internalization within body and inoculation in a susceptible host. Multiplication of tospo virus has been shown in the epithelial cells of midgut, muscle cells surrounding the gut and salivary gland cells of thrips. Eleven thrips species are recorded to transmit twenty tospo viruses worldwide. In India, only six thrips species are reported to transmit six tospo viruses so far. However, the first study on thrips-tospo virus was reported in 1981.Though, the research on tospo viruses was initiated in India during 1960s very few reports are there about vector resistance.

Thrip species such as Thripspalmi and Scirtothripsdorsalis form another major group which is important as vectors of virus diseases of tomato. These pests destroy seedlings before they have a chance to become hardy. They can thrive on expanding plant tissue - the flower buds, tomato fruits, as well as growing stems and leaves. In addition, thrips can harbour tomato spotted wilt (TOSPO) virus, which can cause severe damage. Tospo virus infection is known to induce a suite of symptoms on its host plants including leaf speckling, mottling, chlorotic, and necrotic lesions of various shapes, sunken spots, etches, ring spots, stunting, yellowing, and wilting (David et al., 2011). Both larval and adult stages of thrips vectors can actively feed on virus infected host plants, but only early larval instars can acquire the virus and later instar larvae and adults can transmit the virus after a latent period (Ullman et al., 1997, Persley et al., 2006). The major attention is because they cause direct and indirect damage. The direct injury and the virus disease result in discoloration of fruits, thus lowering the quality of the fruits which is almost $23.7 \%$ yield loss found by Kagezi et al., (2001). Host plant resistance can be an important component of IPM programs. Resistant plants can help maintain pest populations below economic injury levels and are usually compatible with other control methods, in addition to being ecofriendly.

Information on insect resistance levels among a large number of accessions and their underlying resistance mechanisms would be very useful for tomato breeders worldwide. The objective of this study was to characterize all available wild accessions of AVRDC - The World Vegetable Center's genebank for trichome types, and to evaluate their resistance to thrips. Finding resistance source is the most important criteria to combat against different insect complex. As thrips can play more destructive role as a vector, getting vector resistance by field and lab screening was the interest of our study.

\section{Materials and Methods}

\section{Field experimental design}

The present investigation was carried out at M/S I@ B Seeds, Kengeri, Uttarahalli, Bengaluru, Karnataka and a monitoring survey was conducted for two consecutive growing seasons in 2017 dry season followed by 2018 dry season. Five wild accessions procured from AVRDC Taiwan were transplanted in a randomized block design with four replications. All the agronomic practices were followed except plant protection according to the package of practices. Five plants/plot and as a total twenty plants were randomly selected in each genotype for taking count and visually rated for thrips infestation based on upward leaf curl damage. The rating was used for recording the thrips infestation done at six different phonological intervals i.e. $3^{\text {rd }}, 6^{\text {th }}$, $9^{\text {th }}, 12^{\text {th }}$ and $15^{\text {th }}$ weeks after transplanting with symptoms severity on a $0-3$ scale as per the standard procedure given by Niles(1980) as Scoring category Symptoms 0 - No leaf curling (healthy plant) $1<25 \%$ (1-25\%) low curling, 26-50\% (26-50\%) moderate curling, $51-75 \%(51-75 \%)$ heavy curling. 
Data were collected on thrips occurrence, from each selected plant, by counting and collecting thrips which were found on the underside of the three top-most, fullyexpanded tomato leaflets. Thrips samples were collected in the late morning hours by gently tapping on the leaves, which dislodged the thrips from the leaves to white plastic trays placed under each plant. Using camel hair brushes, the thrips were transferred to vials containing $60 \%$ ethanol, glycerin, and acetyl glyceric acid (AGA) fluid in the ratio 10:1:1, respectively for preservation of futures (Palmer et al., 1989; Palmer, 1990). The vials of thrips were then taken to the laboratory for counting and identification. Thrips were mounted and identified under a compound light microscope (manufactured by Leica), using the procedure described by Palmer (1990), at a magnification of 40x. Thrips complex were identified upto specis level from NBAII, Hebbal. Four major different species were recorded from two field trials. Gynaikothrips uzelii, Scirtothrips dorsalis, Thrips palmi and Thrips hawaiiensis were recorded from the collected thrips samples.

Among our identified thripspecis, two were reported as TOSPO vector till now in India i.e. Thrips palmi and Scirtothrips dorsalis. Only one vector species was further selected for screening the accessions under laboratory condition. Scirtothrips dorsalis was used for lab assay for screening those accessions. S.dorsalis culture was maintained in susceptible chilli cultivar planted in polybags by following no sprays and on capsicum fruits under laboratory condition at 16 light and 8 dark hours.

Leaf Disc Tests: S. dorsalis was collected from reared on susceptible Chilli (Capsicum annum) in an insect greenhouse at $25^{\circ} \mathrm{C}$ and $70 \%$ relative humidity (Koschier et al., 2000). Adult female thrips were starved for 24 hours in a cage with only water (Murai and Loomans, 2001). Leaf discs (4 $\mathrm{cm}$ in diameter) were taken from fully opened leaves using a leaf punch and placed in Petri dishes on water agar $(15 \mathrm{~g} / \mathrm{l}$ agar) with the lower (abaxial) side upward and placed in equidistance manner.

Ten starved female adult thrips and larvae were placed on each leaf disc using a wet brush separately. Dishes were closed using plastic cups having mesh attached for aeration and to prevent thrips from escaping and placed in a climate room at $24^{\circ} \mathrm{C}, 16 \mathrm{~h}$ light, $70 \%$ RH. There were six replicates for each accession. The extent of damage based on feeding scars (by larvae) and destruction by thrips (adults) feeding, oviposition and secretion were rated together using a relative scale from 0 (no damage) to 3 (severe damage) two days after inoculation. Per cent larval mortality was calculated by observing till 6 days regularly after release of second instar larvae onto the leaf disc.

\section{Physiological trait (trichome type and density) analysis}

Trichome types were identified by observing under Scanning electron microscope and classified according to Luckwill (1943) and determined the types present on both abaxial and adaxial sides. Density of trichome was carried out by counting the trichome numbers present in $\mathrm{mm}^{2}$ area.

Presence of trichome type and density was further correlated with larval mortality, field thrips count/tap and egg laying preference by adult vector species i.e. S. dorsalis. Mean number of thrips count, egg count and leaf trichome count were subjected to statistical analysis using Analysis of Variance (ANOVA) after suitable transformation.

\section{Results and Discussion}


Among the thrips complex identified in 2018 summer season had more number of vector species rather than 2017 field data (Fig. 1) Gynaikothrips uzeli catch was more per tap during 2017 flowering stage whereas during 2018, other major tospo vector species were more.

Two season thrips count is represented in below (Table 1). Two accessions viz., $S$. galapagense (VI037241), S. cheesmaniae (VI037240) have shown high resistance to any of the thrips species with 0 to 1 thrips/tap where as in susceptible accession S.lycopersicum (CL5915) it was consistently more for both the season. In S. habrochaites (LA1777) and S. habrochaites var glabratum (VI030462) the Gynaikothri psuzeli catch was more during its flowering stage in 2017 whereas very less in 2018. Although except S.lycopersicum (CL5915), all the other four wild accessions have shown resistance with no visual leaf curling. Lab choice bioassay has shown significant difference in egg laying preference than susceptible S.lycopersicum (CL5915), to all other four resistant accessions. No-choice lab assay has shown high larval mortality and less mobility and feeding preference to all four resistant accessions. More than 90 per cent larvae died in resistant wild accession especially in $S$. galapagense (VI037241), S.cheesmaniae (VI037240) followed by more than 60 per cent mortality in S.habrochaites (LA1777) and S. habrochaites var glabratum (VI030462) in laboratory bioassay (Fig. 2).

According to Fery and Schalk (1991) resistant cultivars support larval and adult thrips populations as large as those in susceptible cultivars, but with significantly less damage done. Our thrips catch per tap was not statistically significant for $S$. habrochaites (LA1777) and S. habrochaites var glabratum
(VI030462) with susceptible $S$. lycopersicum (CL5915), although egg laying and mortality rate differed significantly among those two accessions and susceptible accession which are at a line with their findings.

One way ANOVA followed by Tukey HSD test showed that S. galapagense (VI037241) and S. cheesmaniae (VI037240) are significantly differed than Susceptible S.lycopersicum (CH45) in terms of percent larval mortality $\mathrm{F}(4,25)=75.49, \quad \mathrm{p}<.001$. Feeding scar on no choice assay was scored as scale 2 in susceptible accessions but 0 to almost nill in other four enties (Fig. 3).

The dense glandular trichomes (Fig. 4) conferred resistance by trapping the thrips adults and larvae and also have strong negative impact on its movement and feeding.

High glandular trichome density has shown resistance to other sucking pest like white flies, Tetranychus mite and also lepidopteran pests like T.absoluta (Rakha et al., 2017, Sridhar et al., 2019). Our field as well as lab studies shows high resistance of thrips population in case of $S$. galapagense (VI037241) and S. cheesmaniae (VI037240) which can be used as a resistant source for future breeding lines.

Wild accession from different province have some resistance trait like presence of glandular trichome "type iv" which shows high resistance against thrips by conferring hindrance in mobility causing less egg laying preference, less feeding and high mortality.

Finding any variety which can help to combat the vector thrips species can help in managing the damage caused by thrips and also by TOSPO disease (Table 2). 
Table.1 Comparison of percent larval mortality of Scirtothrips dorsalis

\begin{tabular}{|c|c|c|c|c|c|c|c|}
\hline \multicolumn{8}{|c|}{ Multiple comparisons } \\
\hline \multicolumn{8}{|c|}{ Dependent Variable: percent mortality } \\
\hline \multirow{2}{*}{\multicolumn{3}{|c|}{ (I) wild accessions }} & \multirow{2}{*}{$\begin{array}{c}\text { Mean } \\
\text { Difference } \\
\text { (I-J) }\end{array}$} & \multirow[t]{2}{*}{$\begin{array}{l}\text { Std. } \\
\text { Error }\end{array}$} & \multirow[t]{2}{*}{ Sig. } & \multicolumn{2}{|c|}{$\begin{array}{l}\text { 95\% Confidence } \\
\text { Interval }\end{array}$} \\
\hline & & & & & & $\begin{array}{l}\text { Lower } \\
\text { Bound }\end{array}$ & $\begin{array}{l}\text { Upper } \\
\text { Bound }\end{array}$ \\
\hline \multirow{20}{*}{$\begin{array}{l}\text { Tukey } \\
\text { HSD }\end{array}$} & \multirow[t]{4}{*}{ S.galapagense } & S.cheesmaniae & -3.55556 & 4.11804 & .907 & -15.6497 & 8.5386 \\
\hline & & S.habrochaites & $22.27778^{*}$ & 4.11804 & .000 & 10.1836 & 34.3719 \\
\hline & & S.habrochaitesvarglabratum & $21.27778^{*}$ & 4.11804 & .000 & 9.1836 & 33.3719 \\
\hline & & S.lycopersicum & $59.98611^{*}$ & 4.11804 & .000 & 47.8920 & 72.0803 \\
\hline & \multirow[t]{4}{*}{ S.cheesmaniae } & S.galapagense & 3.55556 & 4.11804 & .907 & -8.5386 & 15.6497 \\
\hline & & S.habrochaites & $25.83333^{*}$ & 4.11804 & .000 & 13.7392 & 37.9275 \\
\hline & & S.habrochaitesvarglabratum & $24.83333^{*}$ & 4.11804 & .000 & 12.7392 & 36.9275 \\
\hline & & S.lycopersicum & $63.54167^{*}$ & 4.11804 & .000 & 51.4475 & 75.6358 \\
\hline & \multirow[t]{4}{*}{ S.habrochaites } & S.galapagense & $-22.27778^{*}$ & 4.11804 & .000 & -34.3719 & -10.1836 \\
\hline & & S.cheesmaniae & $-25.83333^{*}$ & 4.11804 & .000 & -37.9275 & -13.7392 \\
\hline & & $\begin{array}{l}\text { S. habrochaites var } \\
\text { glabratum }\end{array}$ & -1.00000 & 4.11804 & .999 & -13.0941 & 11.0941 \\
\hline & & S.lycopersicum & $37.70833^{*}$ & 4.11804 & .000 & 25.6142 & 49.8025 \\
\hline & \multirow[t]{4}{*}{ S.habrochaitesvarglabratum } & S.galapagense & $-21.27778^{*}$ & 4.11804 & .000 & -33.3719 & -9.1836 \\
\hline & & S.cheesmaniae & $-24.83333^{*}$ & 4.11804 & .000 & -36.9275 & -12.7392 \\
\hline & & S.habrochaites & 1.00000 & 4.11804 & .999 & -11.0941 & 13.0941 \\
\hline & & S.lycopersicum & $38.70833^{*}$ & 4.11804 & .000 & 26.6142 & 50.8025 \\
\hline & \multirow[t]{4}{*}{ S.lycopersicum } & S.galapagense & $-59.98611^{*}$ & 4.11804 & .000 & -72.0803 & -47.8920 \\
\hline & & S.cheesmaniae & $-63.54167^{*}$ & 4.11804 & .000 & -75.6358 & -51.4475 \\
\hline & & S.habrochaites & $-37.70833^{*}$ & 4.11804 & .000 & -49.8025 & -25.6142 \\
\hline & & S.habrochaitesvarglabratum & $-38.70833^{*}$ & 4.11804 & .000 & -50.8025 & -26.6142 \\
\hline
\end{tabular}

*. The mean difference is significant at the 0.05 level. 
Fig.1 Occurrence of Thrips species (in percentage) from collected samples
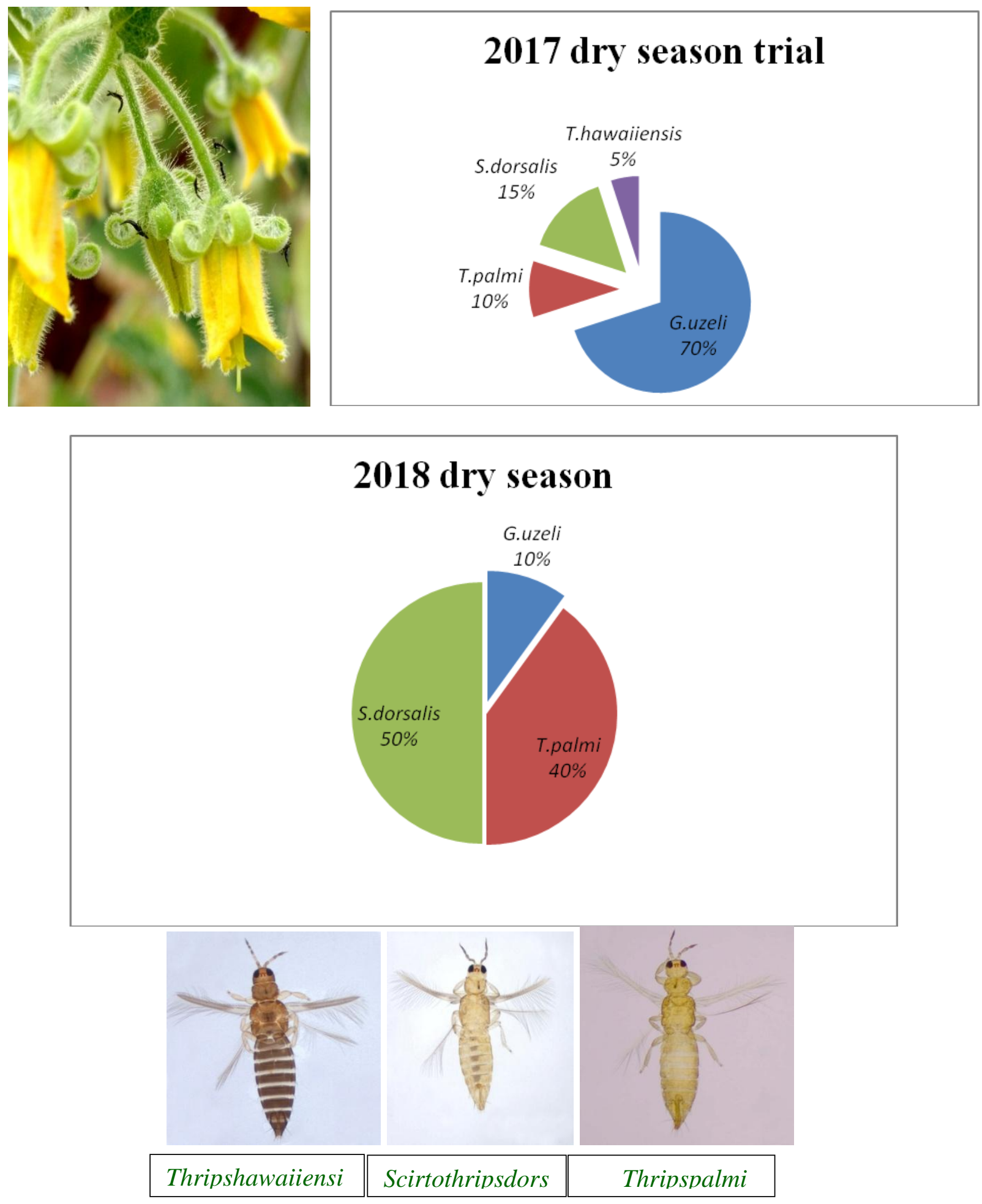
Fig.2 No choice assay and larval mortality in (\%)

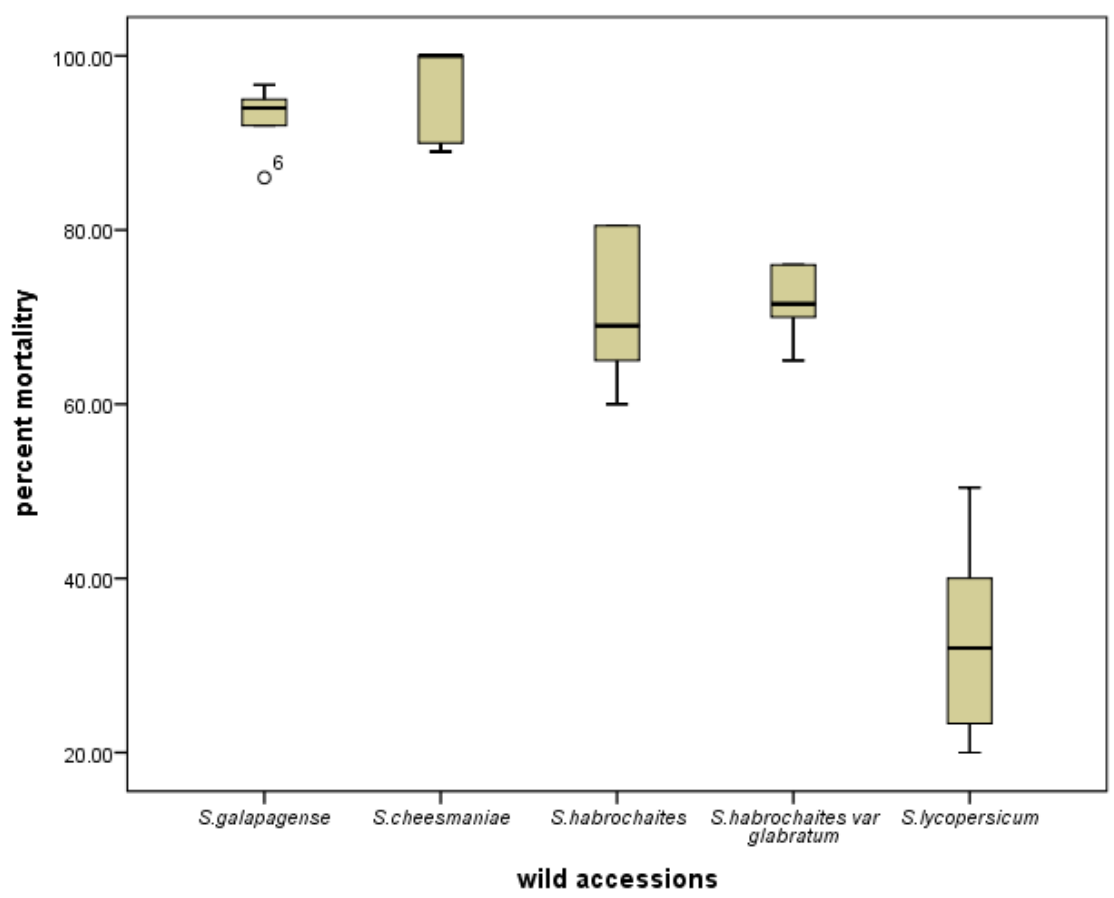

Fig.3 Egg laying assay of Scirtothrips dorsalis under laboratory condition

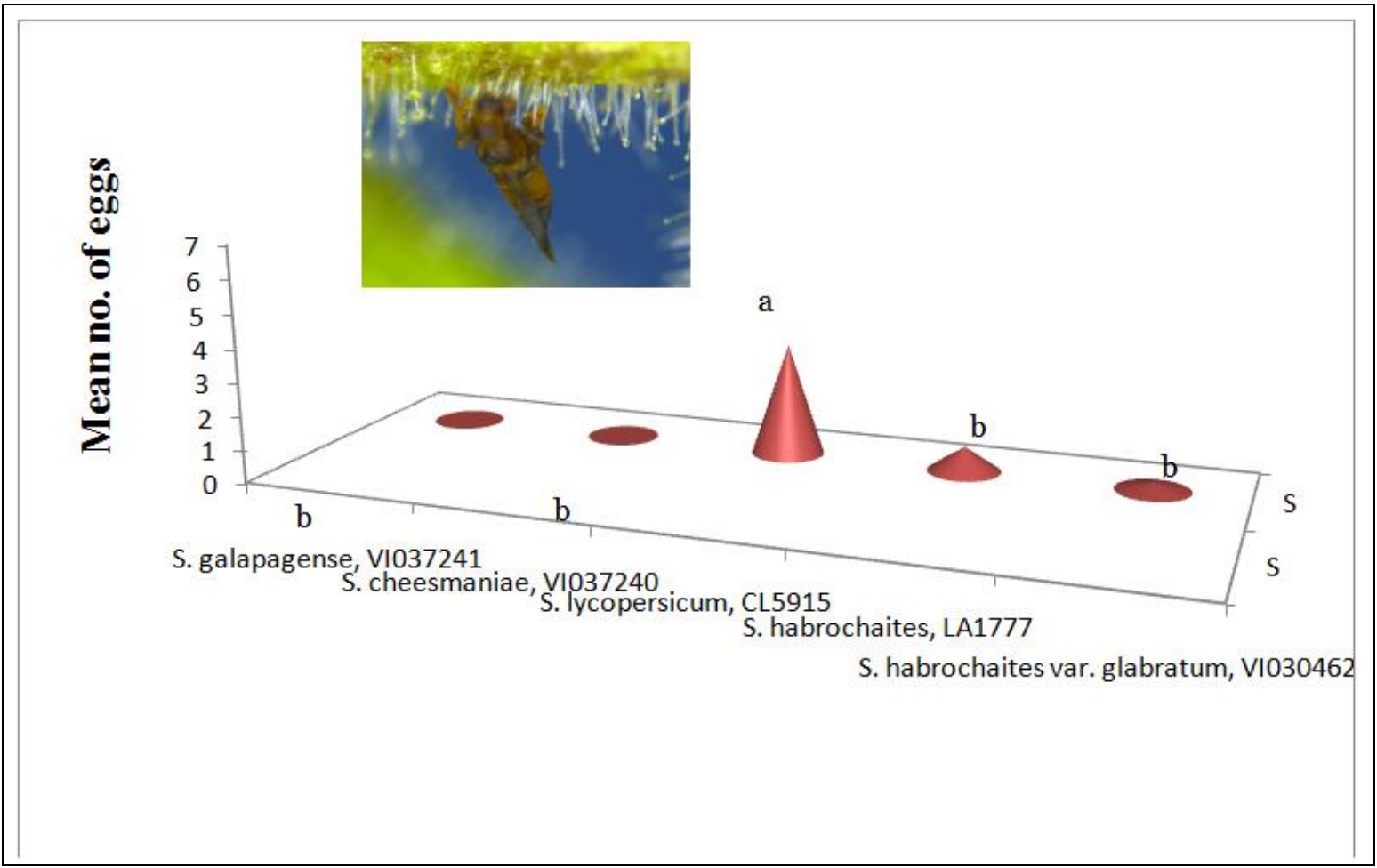


Table.2 Trichome density, laboratory egg laying assay and larval mortality assay

\begin{tabular}{|c|c|c|c|c|}
\hline & $\begin{array}{c}\text { total } \\
\text { glandular }\end{array}$ & $\begin{array}{c}\text { total non- } \\
\text { glandular }\end{array}$ & $\begin{array}{c}\text { Egg laid in } \\
\text { choice assay }\end{array}$ & $\begin{array}{c}\text { Per cent larval } \\
\text { mortality }\end{array}$ \\
\hline S.galapagense,VI037241 & $22.12^{\mathrm{a}}$ & $0.33^{\mathrm{c}}$ & $0(0.70)^{\mathrm{b}}$ & $92.94(74.98)^{\mathrm{b}}$ \\
\hline S.chesmaniae, VI037240 & $19.26^{\mathrm{b}}$ & $0.27^{\mathrm{c}}$ & $0(0.70)^{\mathrm{b}}$ & $96.5(83.09)^{\mathrm{a}}$ \\
\hline $\begin{array}{c}\text { S.habrochaites,LA1777 } \\
\text { S. habrochaitesvar } \\
\text { glabratum,VI030462 }\end{array}$ & $8.57^{\mathrm{c}}$ & $17.42^{\mathrm{b}}$ & $0.5(0.9)^{\mathrm{b}}$ & $70.66(57.40)^{\mathrm{c}}$ \\
\hline S.lycopersicum,CL5915 & $5.79^{\mathrm{d}}$ & $23.96^{\mathrm{b}}$ & $0.33(0.87)^{\mathrm{b}}$ & $71.66(57.887)^{\mathrm{c}}$ \\
\hline SEM & $2.02^{\mathrm{e}}$ & $19.23^{\mathrm{a}}$ & $3.33(1.86)^{\mathrm{a}}$ & $29.16(34.806)^{\mathrm{d}}$ \\
\hline CD(0.05) & 0.48 & 0.5 & 0.02 & 6.14 \\
\hline & 2.262 & 2.32 & 0.429 & 9.77 \\
\hline
\end{tabular}

Values in parenthesis are transformed values.

Fig.4 Thrips adult trapped in high glandular trichome

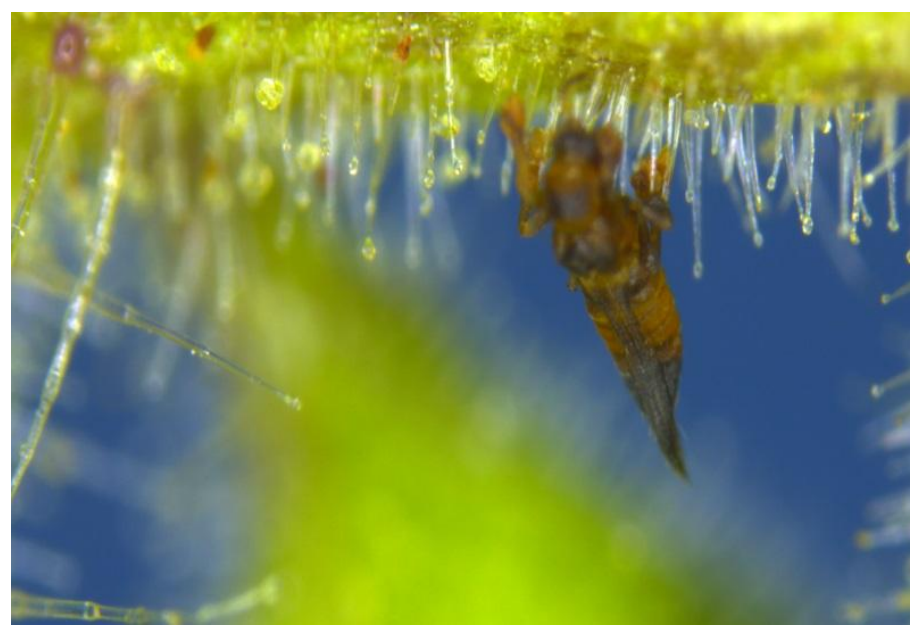

Fig.5 Trichome present in resistant and susceptible accession

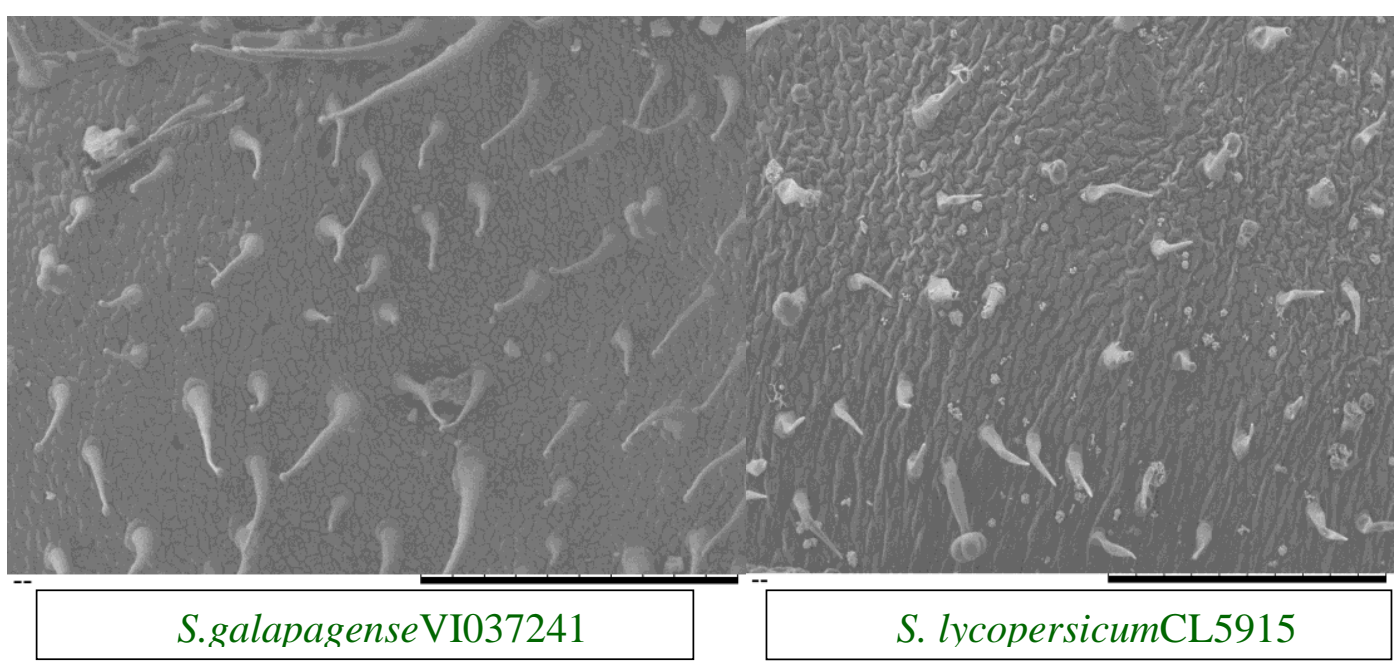




\section{Acknowledgement}

We gratefully acknowledge the financial support and accessions given by World Vegetable centre (Formerly AVRDC), Taiwan to conduct this research work and are also thankful to M/S I\&B Seeds, Kengeri, Bengaluru for providing the necessary laboratory and field facilities for conducting this investigation.

\section{References}

David, G. R., Shimat V. J., Srinivasan, R. and Stanley, D., 2011, Thrips Vectors of Tospoviruses. J. Integ. Pest Mngmt. 1(2):1-10.

Fery, R.L. and Schalk, J.M., 1991, Resistance in pepper (Capsicum annuum L) to Western Flower Thrips [Frankliniella occidentalis (Pergande)]. HortScience 26: 1073-1074.

Fery, R.L. and Schalk, J.M., 1991, Resistance in pepper (Capsicum annuum L) to Western Flower Thrips [Frankliniella occidentalis (Pergande)]. Hort Science, 26: 1073-1074.

Kagezi E.L., Kyamanywa S., Akemo M.C., Luther G., Erbaugh, M., 2001.Damage-yield relationships of major pests of tomatoes in central Uganda. Integrated Pest Management Collaborative Research Support Program Annual Report 8: 259-262.

Karungi, J., Agamile, P., Muhumuza, E., Sabiiti, E.N., Kyamanywa, S., 2009, Effect of intercropping and a biopesticide on population dynamics of two aphid species, Brevicoryne brassicae and Aphis gossypi (Homoptera: Aphididae). Poster published as proceedings of the 6th International IPM Symposium. Oregon, USA, www.ipmcenters.org/ipmsymposium0 9/abstracts.cfm. Accesed: 24-26
March 2009.

Koschier, E.H., DE Kogel, W.J. AND VISSER, J.H., 2000. Assessing the attractiveness of volatile plant compounds to Western Flower Thrips Frankliniella occidentalis. Journal of Chemical Ecology 26: 2643-2655.

Luckwill, L.C. 1943, The genus Lycopersicon: a historical, biological and taxonomic survey of the wild and cultivated tomatoes. Aberdeen University Press, Aberdeen, p 44.

Murai, T., and Loomans, A.J.M., 2001, Evaluation of an improved method for mass-rearing of thrips and a thripsparasitoid. Entomologia Experimentalis Et Applicata 101: 281289.

Niles, G.A., Breeding cotton for resistance to insect pests. In breeding plant resistance to insects. New York, 1980, 337-369.

Palmer, J.M., 1990, Identification of the common thrips of tropical Africa (Thysanoptera: Insecta). Trop. Pest Manage. 36 (1): 27-49.

Palmer, J.M., Mound, L.A., DU, Heaume, G.J. 1989, Thysanoptera. Wallingford, CAB International, British Museum Natural History, Wallingford, 73 pp.

Persley, D.M., Thomas, J.E. AND Sharman, M. 2006. Tospoviruses: an Australian perspective. Australasian Plant Pathology 35: 161-180.

Rakha, M., Bouba, N., Ramasamy, S., Regnard, J., and Hanson, P.,2017, Evaluation of wild tomato accessions (Solanum spp.) for resistance to twospotted spider mite (Tetranychusurticae Koch) based on trichome type and acylsugar content. Genet Resour CropEvol, 64:10111022

Rakha, M., Hanson, P., Ramasamy S., 2017, Identification of resistance to BemesiatabaciGenn.in closely related 
wild relatives of cultivated tomato based on trichome type analysis and choice and no-choice assays. Genet Resour Crop Evol.64:247-264 Doi:10.1007/s10722-015-0347.

Rakha, M., Never, Z., Sevgan, S., Musembi, M., Ramasamy, S., Hanson, P., 2017, Screening recently identified whitefly/spider mite-resistant wild tomato accessions for resistance to Tuta.absoluta.Plant Breeding.1-7
Sridhar, V., Thammanna, A.S., Rao, V.K., Padavala, S. and Hanamant S.G., 2019, Trichome and biochemical basis of resistance against Tutaabsoluta in tomato genotypes. Plant Genetic resources., 1-5.

Ullman, D. E., Sherwood, J. L. and German.T. L., 1997.,Thrips as vectors of plant pathogens, In T. Lewis (ed), Thrips as Crop Pests.CAB International, New York. PP. 539-565.

\section{How to cite this article:}

Pritha Ghosh, K. S. Jagadish, M. G. Puroshottama, V. Sridhar and Keshava Reddy. 2019. Screening of Elite Genotypes of Tomato against Major TOSPO Vector- Thrips Complex. Int.J.Curr.Microbiol.App.Sci. 8(12): 2046-2055. doi: https://doi.org/10.20546/ijcmas.2019.812.242 